\title{
Study on the Connotation of "the Argument in Accordance with Confucian Classics"
}

\author{
Gongluo Zhu \\ College of Humanities \\ Kunming University \\ Kunming, China
}

\begin{abstract}
As the cultural phenomenon with far-reaching influence, "the argument in accordance with Confucian classics" is not only the interpretation of Confucian classics, but also a kind of linguistic expression method and meaning generation method. It is not only the method of theoretical construction and academic inheritance, but also a way of thinking.
\end{abstract}

Keywords-the argument in accordance with Confucian classics; the interpretation of Confucian classics; the method of meaning generation; the method of theoretical construction; way of thinking

\section{INTRODUCTION}

Just as the name implies, according to "the argument in accordance with Confucian classics", we could know that it constructs the meaning, and form the discourse or theory based on the classics. In the fifth years of Jianyuan (136 BC), the emperor Wu of Han dynasty established the Five Classics Doctorate of "Poet", "Book", "Etiquette", "the Book of Changes" and "the Spring and Autumn". Since that time, the five classics had been the Confucian classics. The establishment of the Confucian classics is the prerequisite of "the argument in accordance with Confucian classics" Since then, in more than two thousand years of feudal society, "the argument in accordance with Confucian classics" has become significant and important cultural phenomenon. In today's society, the Confucian classics do not have the dominant and authoritative political ideology. However, "the argument in accordance with Confucian classics" still potentially affects our way of thinking and discourse.

"The argument in accordance with Confucian classics" has a far-reaching impact on our ideology and culture. However, the study on "the argument in accordance with Confucian classics" has not been deep thoroughly by the academic circles. And even, the connotation of "the argument in accordance with Confucian classics" has yet to be further investigated. In this article, it argues that the connotation of "the argument in accordance with Confucian classics" can be recognized in many aspects. It is not only the basic method of the elaboration of the Confucian classics, but also the way of language expression, the generation mode of meaning, the way of theory construction, the way of academic inheritance. And even, it has been the way of thinking internally.

\section{THE INTERPRETATION WAY OF THE ClASSICS}

According to the situation of "the argument in accordance with Confucian classics", it is firstly manifested in a series of explanation mechanisms such as preface, biography, note, sparseness and memo created in the process of the interpretation. According to the "thirteen classics explanatory notes and commentaries", we can see the classic interpretation texts that existed before the Southern dynasty in which Liu Xie was born. And Wang Bi and others made the annotation of "The Book of Changes" in Wei dynasty. There is "Kong Anguo comment" in "Book of Documents" in Han dynasty. Zheng Xuan made annotation of Maoheng Biography of "the Book of Poetry" in Han dynasty. Zheng Xuan made the annotation of "the Rites of Zhou", "Etiquette", "The Classic of Rites" in Han dynasty. Du Yu made the annotation of "the Biography of the Spring and Autumn History" in Jin dynasty. He Yan and other notes made the annotation of "Analects" in Wei dynasty. Zhao Qi made the annotation of "Mencius" in Han dynasty.

According to "History of the Han dynasty — Art and Literature", there are more interpretations and texts related to six arts. Its system includes "Biography" (such as "the books of changes" and "Book Biography"), "Inner Biography" (such as "Han's Inner biography of Peoms"), "External biography" (such as "Han's External biography of Peoms"), "Saying" (such as "Lu's Saying to Poems"), "Miscellany" (such as "Yan's Miscellany for Gongyang's Spring and Autumn "), "the complex biography"(such as "Gongyang Zhuan")," the Hiding Meaning"(such as the Hiding Meaning of Zuo's Sping and Autumn), "Souce" ("Lu's (poems)", "Han's (poems)"), "Analysis of Word's Source" ("big and small Xiaho's Old Book), "Interpretation of ancient words" (such as "Mao's Peoms"), "Chapter" (such as "Chapter of big and small Xiahou's Old Book") and so on.

"Biography" (including "Preface") is the commentary and interpretation of the classics, including the elucidation of the sentences of the classics, etc. "Inner Biography" means the disseminated article closely related to the content [1]. "External Biography" list extensive cases which can't entirely explain the main basis of the classics[2]. "Annotation" is equivalent to "Biography". In "Rites Annotation", Jia Gongyan said that the ancient scriptures were difficult to understand, as if the waterway obstruction, 
we must make perfusion to get the circulation. And in "Mao Shi Zheng Yi", Kong Yingda ever said that note should interpret the classics. And the annotation would make the meanings of classics clear [3] ${ }^{610}$. Usually, the "annotation" is related to "dredge". However, there are differences between the "annotation" and "dredge". "Annotation" is used for interpreting the words and phrases. And "dredge" is used for explaining not only the meanings of the original text,but also the meanings of the annotation. So, it also called "Zheng Yi". The "commentary" is the supplement to the original note. In "commentary", the author can take note of his own different opinions [3] ${ }^{189}$. "Talk" could explain the meaning of something. And it originated very early. The "Saying" could make the supplement for the scriptures and the classics. It mainly explains the meaning of the classics. It is different from the writing of criticizing the nominal system [4] ${ }^{533}$. "Miscellany" refers to the interpretation of the classics [5] ${ }^{98}$, such as "Book of Rites." "the Hiding Meaning" is also the comment system, focusing on the interpretation of the original text's hiding meaning [5] ${ }^{287}$. "Analysis of Word's Source" is used to explain the old saying. That is to say, we could use the modern words to explain the ancient sayings. [3] ${ }^{144}$. In other words, "to make the explanation" is "to make the interpretation". And it could use current languages to explain the ancient words. [6] The so-called "Interpretation of ancient words" also refers to the interpretation of the meaning of ancient books. And it is the main form to interpret the classics used by the scholars [7]. "Chapter" refers to the analysis of chapters and the sentence in ancient books [4] ${ }^{534}$.

From the perspective of the above comments, the classics are the starting points for all interpretations. And all of the annotation, the biography, the explanation and the chapter are the interpretation and exertion of the classics. Generally, when we explain the study of Confucianism, we can't violate the rules or break the rules. [8] Therefore, the annotations, the notes, and the explanation show the operation mode of "the argument in accordance with Confucian classics".

\section{THE WAY OF DISCOURSE EXPRESSION}

"The argument in accordance with Confucian classics" is a way of discourse expression. And it wouldn't directly say the ideas or aspirations. With the words of authority, it would express their own meaning in periphrastic ways. For example, one person said that we couldn't go across the street when the light was red. Another person said: "in teachers' words, we couldn't go across the street when the light was red." Obviously, the first person directly states a concept. And the second person does not directly say what they mean. He relates the opinion as told by the authority. With the authority, the opinion of the second person would be correct and convincing. And people wouldn't have the doubt.

Actually, it is a kind of "the argument in accordance with Confucian classics" in daily life. In most cases, "the argument in accordance with Confucian classics" is an effective way of discourse expression. With the authorities (including the traditions, scriptures, verdict, influential people or things, etc.), it could usually stop the debate. Everyone will agree to follow it. And we could have a look at an example. In Liu Yuxi's "On My Modest Room", he wrote "the humble room". However, it expressed the joy of peace and enjoyment of the life with the sentences of "this is a shabby house, and my character is good (I don't feel the humble). At the end of the article, he quoted Confucian words of "what's humble?" in "The Analects". The meaning of this sentence is that virtuous people wouldn't feel shabby, even if they lived in shabby places. Such references reinforce persuasion. And precisely, it is a way of discourse expression of "the argument in accordance with Confucian classics".

With the ways of discourse expression of "the argument in accordance with Confucian classics", if anyone questions it, it will not only question the speaker, but also question the authority quoted by the speaker. And they have to overcome the psychological difficulty. The establishment of the authority has complex social and historical factors. For later people, the authority has prevalent prestige. Most people do not take the risk to challenge the authority. And they would agree to the notion quoted by the speaker. If they indeed want to challenge the authority with the courage of "risking everyone's condemnation", the best solution is to refute the idea with the opinion of the authority. In this way, the debates are conducted with the ways of discourse expression of "the argument in accordance with Confucian classics". It is not hard to find that this kind of discourse expression of "the argument in accordance with Confucian classics" is ubiquitous in life. It is not only individual behavior, but also social behavior [9].

\section{THE WAYS OF MEANING GENERATION}

Whitehead, a British philosopher said: "Western philosophy was a series of footnotes to Plato in twenty and five centuries." [10] This remark illustrates the far-reaching impact of Plato on Western philosophy. In China, Confucius was in Jasper's so-called "axis era". And his Confucian philosophy is also constantly annotated, interpreted and deduced by his descendants.

Zhu Xi said: "Generally, the words of the sages are mostly the sprout. It should be developed by the descendants. However, these annotations must follow the meanings expressed by the sages." [11] "The development of the classics" annotated by the descendants is the discourse expression of "the argument in accordance with Confucian classics". "The stretch and development" is quoted from "the Book of Changes". And it means "the stretch and development of the classics". [12] "Annotation" is "the explanation of the classics". "The development" is "the interpretation of the classics". And "the stretch" is the "the development of the classics". In the end, "to follow the sages" is to develop the classics with the logical deduction. It contains two ways. One is "Confucian classics annotates my thought". That is the interpretation and explanation of the classics. The other is the "my notation to Six Classics". And the self-awareness of the main subject was added to the classic. And it gives the new meaning to the classics. Whether it is "Confucian classics annotate my thought" or "my notations to Six Classics", it involves the grasp of classics and the interpretation and exertion of classics. And it constructed the meaning with the way of "the argument in 
accordance with Confucian classics". The interpretation of classic texts is the basic way for the growth of Confucianism and the construction of meaning. It has had an extremely significant and far-reaching impact on the cultural development for thousands of years. [13]

\section{THE WAYS OF THEORETICAL CONSTRUCTION}

"The argument in accordance with Confucian classics" is not only a way of meaning generation. And it naturally contains the theoretical construction. The reason why the theoretical construction method is listed separately is that "theory" is not a general "meaning". And it has rich and profound connotations. It may have both vertical and horizontal influences. In the longitudinal ways, the theory may have the function of connecting link between the preceding and the following. And it would become an important part of the history of the theory. On the horizontal, the theory couldn't have the influence in different fields. And theoretical contention and symphonic may also be produced between contemporary theorists.

And we can have a look at the example. We could talk about the status of the novel. In "History of the Han dynasty", Ban Gu said: "Novelists used to be government officials at low position.Their stories largely came from the gossips and rumors spread around streets and alleys. In Confucian opinion, although it is the school of novelists, we can find the appreciation. However, if you want to implement it for a long time, you may not know what to do with it. And it will not disappear. The novel is written by a man of wisdom in the village. And it must be preserved without forgetting it. If there is a sentence worthy of our adoption, it is the speech of ancient woodcutter and the wild man. (It has the reference value). [14] ${ }^{1745} \mathrm{Ban} \mathrm{Gu}$ thinks that "there are ten genres, and novelists were excluded from the genres". [14] 1746. "Novelists" belong to the "street talk". And it was not observed in the view. Ban $\mathrm{Gu}$ quoted the sentences of "although it is the school of novelists, we can find the appreciation. However, if you want to implement it for a long time, you may not know what to do with it." This sentence is quoted from "The Analects". However, it is not said by Confucius. And it said by $\mathrm{Zi} \mathrm{Xia}$. Ban $\mathrm{Gu}$ deliberately placed the opinion of $\mathrm{Zi}$ Xia under the Confucius. And he intended to highlight the rationality and authority of "the gentleman wouldn't be a novelist". And it reflects the contempt for "novels" and "novelists" [15]. It is theoretical construction of "the argument in accordance with Confucian classics". Of course, Ban Gu didn't say anything absolutely about it. Instead, he left room for the novel. Naturally, the "fiction" has its own value. And it wouldn't disappear. Ban Gu's contempt for the novel has encountered challenges in later generations. However, the skeptics also adopt the method of "the argument in accordance with Confucian classics". And it can be described as "to refute sb. with his own way". In "the prologue of Jiandeng Xinhua", $\mathrm{Qu}$ You said: "at present, I have the book. For the etiquette, the author makes the supplement. And the author persuades people to be good. And we should punish evil. And we should take this principle that the speaker is innocent, and the listeners is to be warned." [16] ${ }^{103}$. We should persuade people to be good, and we also should punish the evil. And it is in line with the principle of "to be good and to punish the evil" in "Spring and Autumn". And the innocent should follow this principle of "Poetry Preface". According to the typical "the argument in accordance with Confucian classics", $\mathrm{Qu}$ You thinks that the novel has an advisory role, and it is beneficial to the world. This is the doubt of Ban Gu's theoretical opinion of "the novel isn't worth to have a look at it". Liang Qichao argues that "novels are the most superior of literature", "to improve the rule from the beginning of the novel" and "to improve the new people from the beginning of new novel" [16] ${ }^{45}$. And this theory greatly highlights the political function of the novel. And Confucian paid attention to the political and cultural literature and art. For example, in the "Mao Shi Preface", "The former king used the Book of Songs to civilize the people, and made them to be polite, generous and ethical." It is consistent with Confucius. Also, it is the theoretical construction of "the argument in accordance with Confucian classics". The above "status quo of the novel" is based on longitudinal theory of "the argument in accordance with Confucian classics". Liang Qichao's theory of novels has a wide range of influence in the late Qing dynasty. Many people support this theory. And it can be regard as the horizontal impact of theoretical construction of "the argument in accordance with Confucian classics".

\section{ACADEMIC RESEARCH METHODS}

According to the opinion of Cao Shunqing and Wang Qing, the academic framework of the ancient Chinese philosophy and literature is actually based on the method of "the argument in accordance with Confucian classics". And it is launched from the inside. It takes the "thirteen classics" as the bone. To make the annotation of the classics is the core of all research. The historiography is the extension of the classics. The Zhu zi' study is the wings of the classics. The sections of the literary collections are the distribution of the Confucian classics. And it constructs academic system with Chinese characteristics [9]. And it may seem like an absolute argument, but it reveals the general fact of "the argument in accordance with Confucian classics"as an academic research method.

From the microscopic point of view, there are also many examples of "the argument in accordance with Confucian classics". We can take the examples as the academic research paradigm. Liu Xie's "Wen Xin" is a typical example of applying "the argument in accordance with Confucian classics". There are 50 articles in "Wen Xin". And they have formed a theoretical system. Each of which can be seen as a single essay. And "the argument in accordance with Confucian classics" is academic research paradigm applied by Liu Xie.

\section{THE WAYS OF THINKING}

In the academic community, it has different definitions, understandings and ways of thinking. The author agrees to the related discourse of "the dictionary of new concept of literature and art". The so-called way of thinking refers to the structure type of thought activity process. The foothold of 
thinking, thinking point of view, the order of thinking are three elements. [17] ${ }^{333}$ According to this definition, we can examine whether "the argument in accordance with Confucian classics" has three elements of the mode of thinking." First, we should have a look at the foothold of thinking. According to "the argument in accordance with Confucian classics", we should take Confucian classics as the starting point of thinking. And the Confucian classics should be the starting point of the "explanation and development" (Zhu Xi). The Confucian classics are the construction of the meaning and the growth of the meaning. Therefore, "the argument in accordance with Confucian classics" has "the foothold of thinking". Second, we should have a look at the perspective of thinking. "The argument in accordance with Confucian classics" is to construct meaning according to the Confucian classics, which determines the thinking angle of subject. It is not Taoist or others. And we should consider whether the meaning is consistent with the Confucian classics. And then, it would stand in accordance with the principle. Therefore, "the argument in accordance with Confucian classics" also has this element of "the perspective of thinking". Third, we should have a look at the order of thought. "The argument in accordance with Confucian classics" is based on the classic and the construction of meaning. And this dynamic process of "explanation and development" also determines the subject's thinking. And it is directional. From the "classics" to "Argument", "classics" is the starting point, and "Argument" is the purpose. So, "the argument in accordance with Confucian classics" should also have this element of "the thinking order". Therefore, "the argument in accordance with Confucian classics" should have all the elements of the mode of thinking. And it is a strict way of thinking [17] ${ }^{333}$.

It is worth noting that the mode of thinking, way of thinking, formation of thinking and thinking content are interrelated and different. The "thinking form" is relative to the content of thinking. It is the external expression of the content of thinking [18]. Thinking mode is to describe the state of thinking from a static state. The thinking way is to reflect the dynamic process of thinking. [17] 333 Cao Shunqing and Wang Qing have made the study on "the argument in accordance with Confucian classics". They take "the argument in accordance with Confucian classics" as the discourse rule and meaning construction mode. Also, "original Tao" and "confluence of channels" can be regarded as a mode of thinking [19]. The author believes that we should have the discussion on the question. As far as the surface is concerned, "the argument in accordance with Confucian classics" is indeed a kind of discourse rules and a way of constructing meaning. However, in its deep sense, "the argument in accordance with Confucian classics" is a dynamic way of thinking and a static mode of thinking; "Yuan Tao", "Zheng Sheng" and "Zong Jing" does not fully display the three elements of thinking (thinking foothold, thinking perspective, thinking order). It can't be regarded as a dynamic thinking way or a static mode of thinking. It should be regarded as thinking content of "the argument in accordance with Confucian classics". And it is the "Argument" of the classics.

\section{CONCLUSION}

As a way of thinking, "the argument in accordance with Confucian classics" has a relative stability. And it determines people's thinking inertia. The author gets such a material. The rules and regulations in late Qing dynasty include the concept of "don't give up words or paper". Since Cang Jie made a book, he wrote the secrets of heaven and earth. The articles flow throughout the universe. Fool people would have the wisdom. The poverty people would have the wealth As for the dangers of human beings and the things of the world, we can make the determination through this book. And the piece of paper should be really cherished. We should be gentleman with awe and veneration. Then, the articles were divided into the words. And we combine them. It would be the classics. In this sense, there is a deep cultural reason for the folk custom of "don't throw away the words". That is to revere the classic. We have to revere the paper with the words. For Confucianism, we should follow it. The custom of "don't give up paper" embodies the thinking inertia of "the argument in accordance with Confucian classics".

\section{REFERENCES}

[1] Luo Bangzhu. Ancient Chinese Knowledge Dictionary [M]. Wuhan: Wuhan University Press, 1988: 137.

[2] Zhu Zinan. Chinese Stylistics Dictionary [M]. Changsha: Hunan Education Press, 1988: 123

[3] Xu Jialu. Dictionary of traditional linguistics [M]. Shijiazhuang Hebei Education Publishing House, 1990.

[4] Li Xiusheng, Zhu Anqun. Dictionary of the Four Books and Five Classics [M]. Beijing: China Federation of Literature and Art Publishing House, 1998.

[5] Zhu Weiqi et al. Concise Dictionary of Ancient Books [M]. Harbin Heilongjiang People's Publishing House, 1990.

[6] Lin Jianming, Wu Yongqi. Dictionary of Cultural History in Qin and Han Dynasties [M]. Shanghai: Chinese Dictionary Press, 2002: 794.

[7] Huang Kaiguo. Dictionary of Classics [M]. Chengdu: Sichuan People's Publishing House, 1993: 168.

[8] Jiang Guanghui. History of Chinese Classic Thought (Vol. II) [M] Beijing: China Social Sciences Press, 2003: 12.

[9] Cao Shunqing, Wang Qing. The mystery of Chinese traditiona academic emergence: "the argument in accordance with Confucian classics" [J]. Zhongzhou Academic Journal, 2012: 5.

[10] [US] Barrett, Yang Zhaoming et al translation. Irrational Person [M] Beijing: Commercial Press, 1995: 128.

[11] Li Jingde edition, Wang Xingxian. Zhu Zi's Language Category [M] Beijing: Zhonghua Book Company, 1986: 1512

[12] Wang Bi note, Kong Yingda el at. Thirteen Classics Explanatory Notes and Commentaries . Zhou Yi Zhengyi [M]. Shanghai: Shanghai Ancient Books Publishing House, 1997: 80.

[13] Cao Shunqing. Comparison between Chinese and foreign literary theory [M]. Jinan: Shandong Education Press, 1998: 401.

[14] Ban Gu, Yan Shi. Han Shu [M]. Beijing: Zhonghua Book Company, 1962

[15] "The hearsay" and "the advice" also shows that its value is limited.

[16] Huang Lin, Han Tongwen. Selection of ancient Chinese novels (vol 1) [M]. Nanchang: Jiangxi People's Publishing House, 2000.

[17] Lv Zhimin. Dictionary of New concept of Literary Theory [M] Beijing: Culture and Arts Publishing House, 1990.

[18] The thinking content reflects the specific knowledge of the object which being studied. The thinking form is the reflection of specific objects and their attributes. And the basic forms of thinking are concepts, judgments and reasoning.

[19] Yu Weiguo. Analysis on the discourse expression of Confucian "the argument in accordance with Confucian classics" [J]. Inner Mongolia Social Sciences, 2009 (4). 